\title{
TAXONOMY STUDY OF SOME MEMBERS OF LAMIACEAE THROUGH MORPHOLOGICAL TRAITS AND EFFECTS ON GENERAL CONDITION OF THE HONEY BEE (Apis mellifera L.)
}

\author{
Salama A.S. ${ }^{1,2}$ and El-Shabasy A. ${ }^{2 *}$ \\ ${ }^{1}$ Department of Science, Jazan University, KSA \\ ${ }^{2}$ Department of Science, Damanhour University, Egypt
}

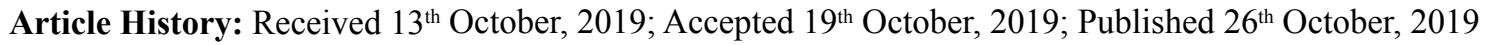

\begin{abstract}
This study illustrated the differentiation among some selected members of Lamiaceae family; Lavandula coronopifola, Ocimum basilicum, Ocimum filamentosum, Orthosiphon thymiflorus, Otostegia fruticosa and Plectranthus asirensis according to morphological characters and the effects of plant extracts on some selected parameters describing the general condition of honeybees Apis mellifera L. like body weights, head weights, head diameters, pharyngeal gland conditions (acini number and canal diameter). Whole plant species were extracted in distilled water. Three cages were used with 100 workers per one. Bees fed on sugar syrup with plant extracts during 12 and 18 days. There were plant species which promoted the physiological conditions of bees but other inhibited them. Similarity matrix and cluster analysis were constructed. Ocimum basilicum and Ocimum filamentosum were close to each other while Otostegia fruticosa and Plectranthus asirensis were distantly related to each other.
\end{abstract}

Keywords: Lamiaceae; Honey Bee; Hypopharyngeal Gland.

\section{INTRODUCTION}

Lamiaceae is just called the mint family which is regarded as an important medicinal plant family. It contains about 236 genera and more than 6000 species. It has great diversity and variety with a cosmopolitan distribution. Species inhabit different natural ecosystems whether wild or cultivated. Most of the species of this family are aromatic and medicinal plants (Lawrence 1992).

The aromatic essential oils are mostly present in leaves, however, they can be found in all aboveground parts of the plants. Many species are valuable in flavoring, cosmetic, perfumery fragrance, pesticide, and pharmaceutical industries (Ozkan 2008). Most of the members of the family Lamiaceae are widely used as a traditional medicine like basil (Ocimum spp.), lavender (Lavandula angustifolia Mill.) and rosemary (Rosmarinus officinalis L.) (Licina et al. 2013).

The honeybee (Apis mellifera) are social insects and live together in nests or hives. Honeybees belong to the order Hymenoptera. They are ideal for behavioral study because they live in welldefined and large family groups (Hellmich et al. 1985). The tasks of worker honeybees change according to changing in environments like colony duties, aging, and production of new workers or increased nectar flow (Le Conte et al. 2001). The way of feeding affects the condition of worker behavior such as nursing larvae, nectar processing or outside responsibilities of guarding and foraging (Leoncini 2002; Leoncini et al. 2004). The presence of such natural chemical substances as ester compounds may inhibit task mediation in honeybee colonies (Trhlin et al. 2011).

The objective of this study was to differentiate among some selected members of the Lamiaceae family based on the effects of plant extracts on selected parameters describing the general condition of honeybees Apis mellifera L. and the morphological traits of studied plant species

\section{MATERIALS AND METHODS}

\section{Collection of plant materials and preparation}

Plants have been the source for medicinal treatments for thousands of years. Whole plant samples of Lamiaceae species; Lavandula coronopifola, Ocimum basilicum, Ocimum filamentosum, Orthosiphon thymiflorus, Otostegia fruticosa, and Plectranthus asirensis (Figures 1-6 respectively) were collected from Jazan region, Kingdom of Saudi Arabia during April 2018. They were identified by the herbarium of the Biology Department, Faculty of Science, Jazan University. They were washed thoroughly 2-3 times with running tap water and then once with sterile water, 


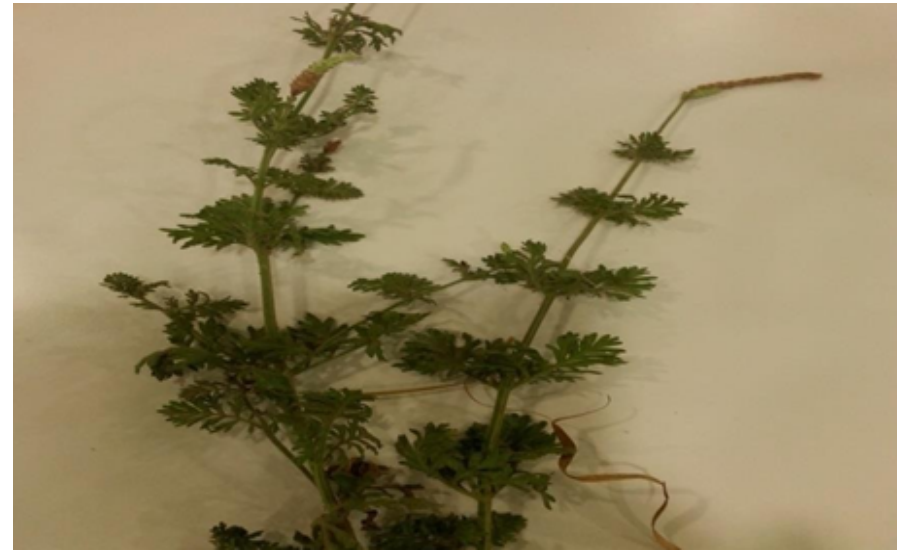

Figure 1: Lavandula coronopifola.

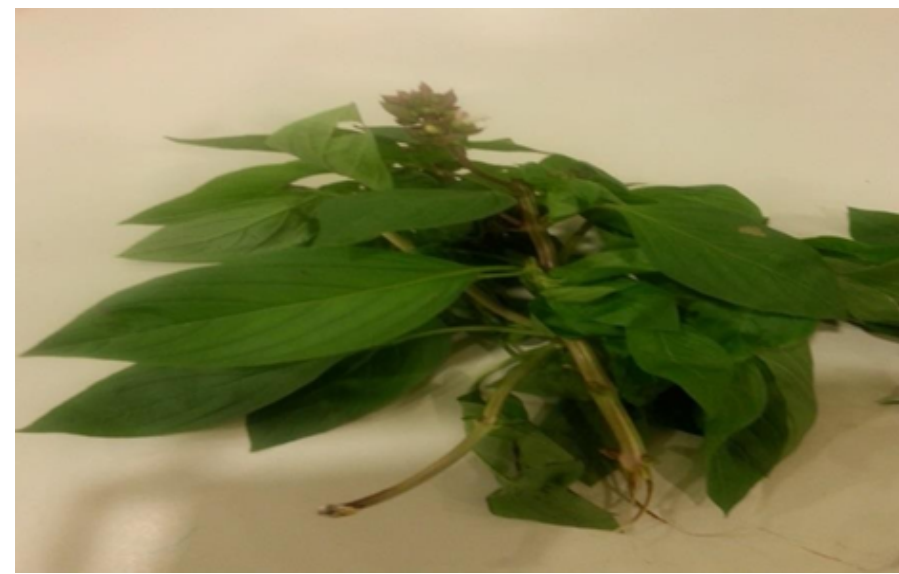

Figure 2: Ocimum basilicum.

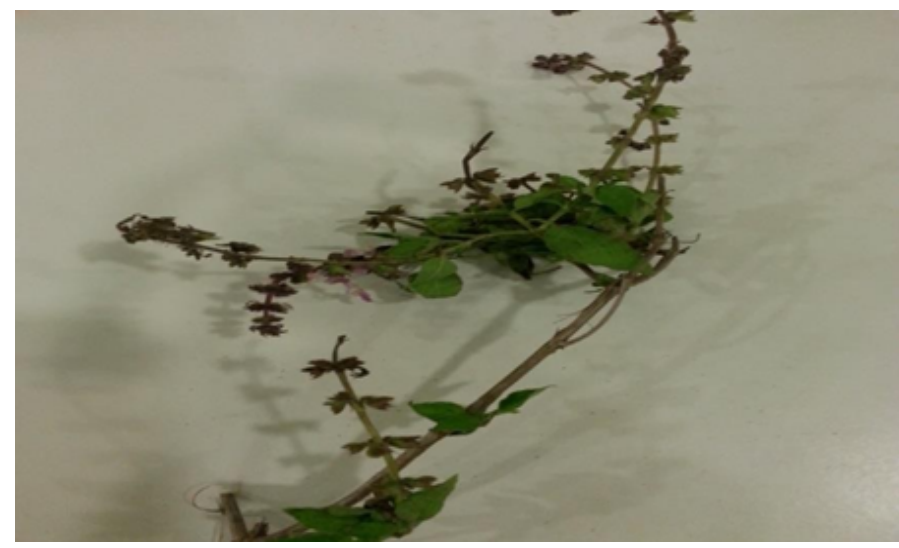

Figure 3: Ocimum filamentosum.

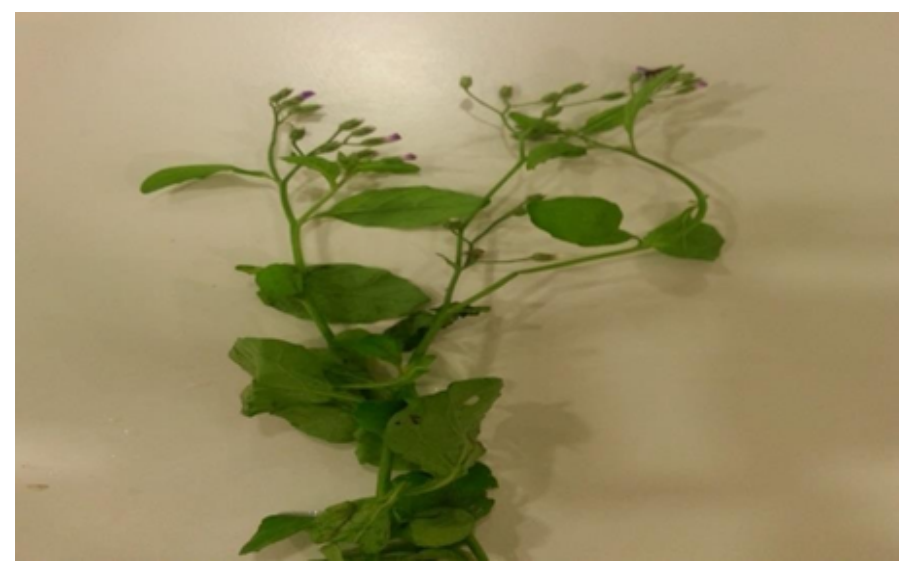

Figure 4: Orthosiphon thymiflorus.

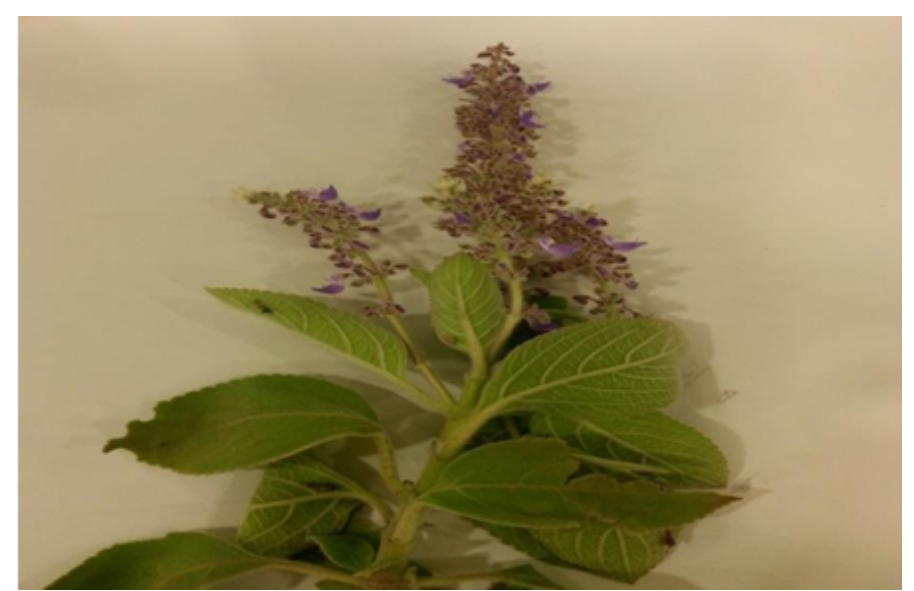

Figure 5: Otostegia fruticosa.

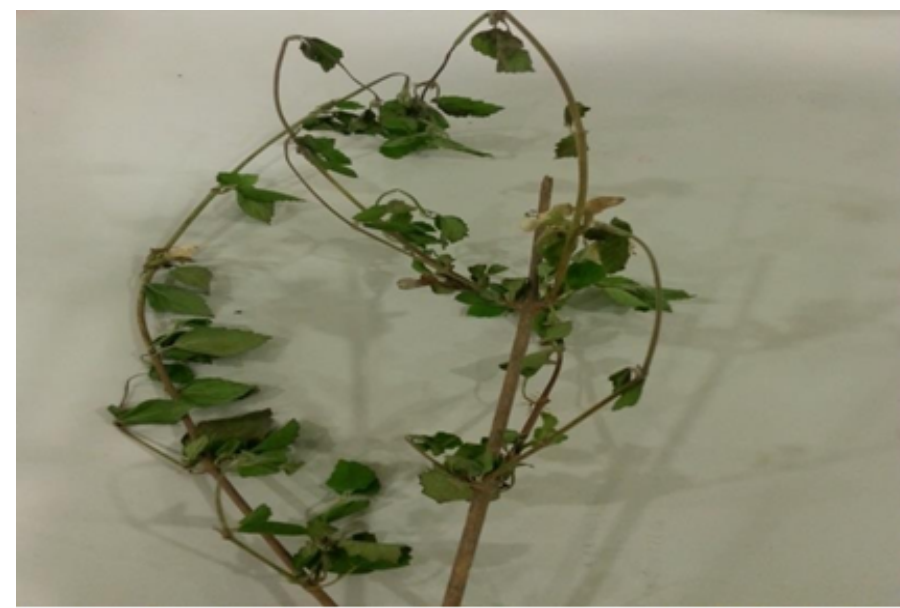

Figure 6: Plectranthus asirensis.

dried, subsequently ground into fine powder. The powder was used for the extraction of crude extracts.

\section{Extraction of the plant material}

20 g Plant powder was mixed with $200 \mathrm{~mL}$ of sterile distilled water in conical flasks. Each Extraction was carried out in an orbital shaker for 6 hours at room temperature (Sultana et al. 2009), filtered and the residue was extracted twice. The combined supernatants were dried in a rotary evaporator and stored in a cool dry place till analysis.

\section{Honeybee preparation}

The experiment was run in April and replicated three times (three cages). Each cage was settled with 100 worker bees collected from mountain combs. Bees were fed sugar syrup at 3:2 concentration ( 3 parts of sugar and 2 parts of water) with an addition of $5 \%$ standardized plant extracts. Cages were kept in an incubator at $25^{\circ} \mathrm{C}$. Every day the number of larvae and syrup consumption were recorded. After 12 and 18 days bees were killed by freezing for analysis. The same previous method was used to count the number of square inches of stored pollen by the field workers (foragers). One pollen cell has about $0.66 \mathrm{~g}$ and one square inch of pollen weights about $16.5 \mathrm{~g}$.

Pollen amounts $(\mathrm{g})=$ Area of pollen stored (square inches) $\times$ 0.1459 
Where, $0.1459=$ amount in grams of stored pollen in one square inch, based on averages calculated according to Ismail (2006). Estimation of honey production was carried out by measuring capped honey cells areas and transformation of squares into weight (Kg) according to Rohlf (1993) using the following formula:

Honey yield in $\mathrm{Kg}=$ Area of honey (square inches) $\times 10.64$ $\mathrm{g} / 1000$

where: 10.64=amount in grams of honey in one square inch, based on averages calculated from unsealed and sealed honey from combs of different thicknesses.

\section{Biological activity assay}

Subsequently, the bees were weighed, measured their dimensions and dissected to examine their hypopharyngeal glands. The degree of hypopharyngeal gland development scored using a scale to determine acini number and canal diameter. The samples were viewed using a binocular microscope at 100x magnification. A fragment of the dissected hypopharyngeal gland was placed on a slide in a drop of water. Each series also involved examinations of non-caged bees collected directly from the hive on the day experiments had started (control). The results were analyzed statistically by means of the Duncan test and the significance of differences was measured at $\alpha \leq 0.05$.

Table 1: Tabular summary showing the morphological characters for the studied species, where 1: Lavandula coronopifola, 2: Ocimum basilicum, 3: Ocimum filamentosum, 4: Orthosiphon thymiflorus, 5: Otostegia fruticosa and 6: Plectranthus asirensis.

\begin{tabular}{|c|c|c|c|c|c|c|c|}
\hline \multicolumn{2}{|r|}{ Species } & 1 & 2 & 3 & 4 & 5 & 6 \\
\hline \multirow{3}{*}{ I- Habit } & a- subshrub & + & - & - & - & + & + \\
\hline & b- perennial & + & + & + & + & + & + \\
\hline & c- aromatic & + & + & + & - & + & + \\
\hline \multirow{3}{*}{ II- Stem } & a- pubescent & - & - & + & - & + & + \\
\hline & d- terete & + & + & + & - & + & + \\
\hline & e- erect & + & + & + & + & + & + \\
\hline \multirow{9}{*}{ III- Leaves } & a- branched & + & + & + & + & + & + \\
\hline & b- fleshy & + & + & + & + & + & - \\
\hline & c- petiolated & - & + & + & + & + & + \\
\hline & d- large & + & + & + & - & - & + \\
\hline & e- ovate to elliptic & - & + & + & + & + & + \\
\hline & f- apex acute & + & + & + & + & + & + \\
\hline & g- exstipulate & + & + & + & + & + & + \\
\hline & h- serrate & - & + & + & + & + & + \\
\hline & i- cuneate base & + & + & + & - & + & + \\
\hline \multirow{17}{*}{ IV- Infloresence } & a- spikes & - & + & + & + & - & + \\
\hline & b- hermaphrodite & + & + & + & + & + & + \\
\hline & c- zygomorphic & + & + & + & + & + & + \\
\hline & d- gamosepalous & + & + & + & + & + & + \\
\hline & e- campanulate calyx & - & + & + & - & - & + \\
\hline & f- pubescent calyx & + & - & + & - & + & - \\
\hline & g- calyx teeth lanceolate & + & + & + & + & - & - \\
\hline & h- corolla tube straight & - & + & + & + & + & - \\
\hline & i- gamopetalous & + & + & + & + & + & + \\
\hline & j- pubescent corolla & - & + & - & - & + & + \\
\hline & k- 4 didynamous Stamens & + & + & + & + & + & + \\
\hline & 1- 2-celled anther lobes & + & - & - & - & + & + \\
\hline & m- confluent anther cells & + & + & + & + & - & + \\
\hline & n- filaments longer than coroola & - & + & + & + & - & + \\
\hline & o- gynobasic style & + & + & + & + & + & + \\
\hline & p- 4-lobed ovary & + & + & + & + & + & + \\
\hline & q- equally stigma & + & + & + & + & - & + \\
\hline \multirow{5}{*}{ V- Fruit } & a- 4 one seeded nutlets & + & + & + & + & + & + \\
\hline & b- glabrous & + & + & + & + & + & + \\
\hline & c- ovoid & - & - & - & + & + & + \\
\hline & d- dark brown & + & + & - & + & - & + \\
\hline & e- size medium & - & + & + & + & + & + \\
\hline
\end{tabular}




\section{Scoring of data and cluster analysis}

The morphological characters of the studied members of the Lamiaceae family and their physiological activity analysis on the honeybees (Apis mellifera) are scored to form phenetic analysis. Similarity matrix and cluster analysis were constructed by using Pclass (Richter et al. 2000) (El-Gazzar et al. 2008) where distances were calculated by using a modification of the Gower coefficient (Gower, 1971;1982). Hierarchic nest clustering and sequential agglomerative were done with UPGMA (Sneath and Sokal, 1973).

\section{RESULTS}

The morphological characters of studied plant species were presented as a binary matrix (0) and (1) (Table 1). This binary matrix was analyzed after adding physiological analysis on bees using NTSYS-pc version 2.11w software (Rohlf, 1993) to calculate the similarity values and generate the phenogram. The Nei genetic similarity index (SI) was used for estimating the similarity between the operational taxonomic units (OTUs) on the basis of the equation; $\mathrm{SI}=2 \mathrm{Nij} /(\mathrm{Ni}+\mathrm{Nj})$, where $\mathrm{Ni}$ and $\mathrm{Nj}$ are the total numbers of characters for species $\mathrm{i}$ and $\mathrm{j}$, respectively and $\mathrm{Nij}$ is the number of common characters shared between species $\mathrm{i}$ and $\mathrm{j}$ (Nei, 1978) (Table 3). After obtaining the similarity matrix, clustering was performed by a distancebased method of hierarchical nested clustering and sequential agglomerative to group species with similar characteristics (Sneath and Sokal, 1973). The graphical representation of the cluster (phenogram) was obtained by the unweighted pair group method of mathematical averages (UPGMA) (Yao, 2007).

The physiological analysis on bees started by measuring the amounts of diets that contained different plant extracts consumed by honey bee workers, it was found that the highest consumption record presented in diet containing Plectranthus asirensis extract while the consumption of the others is almost the same (Table 2).

After 18 days, an increase in body weight was observed in all workers consumed of all plant extracts except who fed on workers fed on diets containing Plectranthus asirensis extract. The significant increase in body weight was recorded for honey bee workers that fed on diets containing Otostegia fruticosa extract while there is slight increase with workers fed on diet containing Orthosiphon thymiflorus extract when compared with the untreated workers (control) (Table 3).

On the other hand, there is an increase in head weight of all workers consumed of all plant extracts except who fed on diets containing Ocimum basilicum extract. The highest head weight of workers was recorded for the diets containing Otostegia fruticosa extract while the lowest one was recorded for workers fed on diets containing Lavandula coronopifola extract (Table 4).

In the present study there is an increase in head diameters of all workers consumed of all plant extracts except who fed on diets containing Plectranthus asirensis extract. The highest head diameters of workers that fed on diets containing Orthosiphon thymiflorus extract while the lowest head width of workers was recorded for diets -containing Lavandula coronopifola extract and the lowest head length was recorded for the sugarcontaining Ocimum basilicum extract (Table 5).

In this study when assessing the development of hypopharyngeal glands, it was found that there was an increase in acini number

Table 2: Average consumption of sugar syrup with the addition of the plant extracts ( $\mathrm{ml} / \mathrm{bee})$.

\begin{tabular}{|c|c|c|c|c|c|c|c|}
\hline Consumption(ml/bee) & After 2 days & After 6 days & After 8 days & After 10 days & After 12 days & After 18 days & Total \\
\hline Control & 0.4 & 0.2 & 0.3 & 0.5 & 0.5 & 0.4 & $2.3^{\mathrm{abc}}$ \\
\hline Lavandula coronopifola & 0.2 & 0.4 & 0.5 & 0.5 & 0.4 & 0.2 & $2.2^{\mathrm{abc}}$ \\
\hline Ocimum basilicum & 0.1 & 0.3 & 0.4 & 0.6 & 0.5 & 0.3 & $2.2^{\mathrm{abc}}$ \\
\hline Ocimum filamentosum & 0.3 & 0.1 & 0.3 & 0.7 & 0.4 & 0.2 & $2.0^{\mathrm{abc}}$ \\
\hline Orthosiphon thymiflorus & 0.4 & 0.1 & 0.4 & 0.2 & 0.3 & 0.7 & $2.1^{\mathrm{abc}}$ \\
\hline Otostegia fruticosa & 0.5 & 0.1 & 0.5 & 0.5 & 0.5 & 0.4 & $2.5^{\mathrm{abc}}$ \\
\hline Plectranthus asirensis & 1 & 0.1 & 0.1 & 1 & 1 & 1 & $4.2^{\mathrm{c}}$ \\
\hline
\end{tabular}

Table 3: Average bodyweight of honey bees fed on sugar syrup with the addition of the plant extracts $(\mathrm{mg})$.

\begin{tabular}{|l|c|}
\hline \multicolumn{1}{|c|}{ Species } & $\begin{array}{c}\text { Workers body weight } \mathbf{1 8} \text { days old (mg) } \\
\text { (mean } \pm \text { SE) }\end{array}$ \\
\hline Control & $118.67^{\mathrm{ab}} \pm 0.92$ \\
\hline Lavandula coronopifola & $177.33^{\mathrm{bc}} \pm 1.81$ \\
\hline Ocimum basilicum & $165.05^{\mathrm{abc}} \pm 0.82$ \\
\hline Ocimum filamentosum & $156.30^{\mathrm{abc}} \pm 1.43$ \\
\hline Orthosiphon thymiflorus & $148.67^{\mathrm{abc}} \pm 1.82$ \\
\hline Otostegia fruticosa & $201.60^{\mathrm{c}} \pm 1.82$ \\
\hline Plectranthus asirensis & $74.19^{\mathrm{a}} \pm 0.62$ \\
\hline
\end{tabular}

Table 4: Average head weight of honey bees fed on sugar syrup with the addition of the plant extracts $(\mathrm{mg})$.

\begin{tabular}{|l|c|}
\hline Species & $\begin{array}{c}\text { Workers head weight 18 days old (mg) } \\
\text { (mean } \pm \text { SE) }\end{array}$ \\
\hline Control & $12.84^{\mathrm{a}} \pm 0.12$ \\
\hline $\begin{array}{l}\text { Lavandula } \\
\text { coronopifola }\end{array}$ & $15.37^{\mathrm{ab}} \pm 0.14$ \\
\hline Ocimum basilicum & $11.35^{\mathrm{a}} \pm 0.10$ \\
\hline $\begin{array}{l}\text { Ocimum } \\
\text { filamentosum }\end{array}$ & $19.50^{\mathrm{b}} \pm 0.18$ \\
\hline $\begin{array}{l}\text { Orthosiphon } \\
\text { thymiflorus }\end{array}$ & $15.87^{\mathrm{ab}} \pm 0.14$ \\
\hline Otostegia fruticosa & $21.62^{\mathrm{b}} \pm 0.19$ \\
\hline Plectranthus asirensis & $17.81^{\mathrm{ab}} \pm 0.16$ \\
\hline
\end{tabular}


of the hypopharyngeal glands in honey bee workers for 18 days fed on diets containing all plant extracts except who fed on diets containing Plectranthus asirensis. Moreover, the highest acini number of the hypopharyngeal glands was recorded for the workers fed on diets containing Otostegia fruticosa extract (941) for 18 days while the lowest acini number of the hypopharyngeal glands was recorded for the diet containing Ocimum basilicum and Lavandula coronopifola extracts (690) for the same age workers. On the other hand, there was a decrease in canal diameter of the hypopharyngeal glands of honey bees workers for 18 days consumed of all plant extracts except who fed on diet containing Ocimum filamentosum and Otostegia fruticosa extracts but after 18 days, there was an increase in canal diameter for all bees except Lavandula coronopifola and Plectranthus asirensis extracts which were used in diet feeding (Table 6).

According to the number of larvae, there was an increase in the number of larvae of honey bee worker that fed on diets that containing all tested plant extracts except those fed on diets containing Ocimum filamentosum and Plectranthus asirensis extracts. The highest larvae number was recorded for workers fed on diets containing Ocimum basilicum extract while the lowest larvae number was Lavandula coronopifola extract when compared with the honey bee workers fed only on sugar syrup (Table 7).

\section{DISCUSSION}

When bees fed on sugar syrup containing plant extracts, their taste properties may alter as compared to pure sugar feeds. The degree of attraction can be measured by consumption assessment by bees. Except for Plectranthus asirensis extract, the attraction

Table 5: Average head diameters of honey bees fed on sugar syrup with the addition of the plant extracts $(\mathrm{mm})$.

\begin{tabular}{|l|c|c|}
\hline \multirow{2}{*}{$\begin{array}{l}\text { Head diameters } \\
\text { species }\end{array}$} & \multicolumn{2}{|l|}{$\begin{array}{l}\text { Workers head diameters 18 days old } \\
(\mathbf{m e a n} \pm \mathbf{S E})\end{array}$} \\
\cline { 2 - 3 } & Width $(\mathrm{mm})$ & Length $(\mathrm{mm})$ \\
\hline Control & $2.58^{\mathrm{ab}} \pm 0.76$ & $3.38^{\mathrm{abc}} \pm 0.95$ \\
\hline $\begin{array}{l}\text { Lavandula } \\
\text { coronopifola }\end{array}$ & $3.26^{\mathrm{abc}} \pm 1.44$ & $4.05^{\mathrm{c}} \pm 1.20$ \\
\hline Ocimum basilicum & $3.67^{\mathrm{abc}} \pm 0.70$ & $3.97^{\mathrm{abc}} \pm 1.12$ \\
\hline Ocimum filamentosum & $3.4^{\mathrm{abc}} \pm 0.74$ & $3.98^{\mathrm{abc}} \pm 0.82$ \\
\hline $\begin{array}{l}\text { Orthosiphon } \\
\text { thymiflorus }\end{array}$ & $4.09^{\mathrm{c}} \pm 1.21$ & $4.42^{\mathrm{c}} \pm 1.25$ \\
\hline Otostegia fruticosa & $4.05^{\mathrm{c}} \pm 1.20$ & $4.20^{\mathrm{c}} \pm 1.18$ \\
\hline Plectranthus asirensis & $1.61^{\mathrm{a}} \pm 0.48$ & $2.05^{\mathrm{a}} \pm 0.58$ \\
\hline
\end{tabular}

Table 6: Acini number and canal diameter $(\mu \mathrm{m})$ of pharyngeal glands of honey bees fed on sugar syrup with the addition of the plant extracts.

\begin{tabular}{|l|c|c|}
\hline \multirow{2}{*}{\multicolumn{1}{c|}{ Species }} & \multicolumn{2}{c|}{ Hypopharyngeal glands } \\
\cline { 2 - 3 } & \multicolumn{2}{|c|}{ 18 days } \\
\cline { 2 - 3 } & Acini no. & Canal diameter $(\boldsymbol{\mu m})$ \\
\hline Control & $680^{\mathrm{ab}} \pm 1.15$ & $21.13^{\mathrm{ab}} \pm 0.54$ \\
\hline Lavandula coronopifola & $690^{\mathrm{ab}} \pm 1.15$ & $20.26^{\mathrm{ab}} \pm 0.17$ \\
\hline Ocimum basilicum & $723^{\mathrm{b}} \pm 1.73$ & $22.00^{\mathrm{ab}} \pm 0.28$ \\
\hline Ocimum filamentosum & $828 \mathrm{~b}^{\mathrm{c}} \pm 1.55$ & $25.27^{\mathrm{abc}} \pm 0.43$ \\
\hline Orthosiphon thymiflorus & $687^{\mathrm{ab}} \pm 0.57$ & $21.46^{\mathrm{ab}} \pm 0.29$ \\
\hline Otostegia fruticosa & $941^{\mathrm{c}} \pm 1.58$ & $28.73^{\mathrm{b}} \pm 0.44$ \\
\hline Plectranthus asirensis & $346^{\mathrm{a}} \pm 0.58$ & $10.57^{\mathrm{a}} \pm 0.16$ \\
\hline
\end{tabular}

Table 7: Number of larvae produced after honey bees fed on sugar syrup with the addition of the plant extracts.

\begin{tabular}{|l|l|l|l|l|l|l|l|}
\hline $\begin{array}{l}\text { No. of larvae } \\
\text { Species }\end{array}$ & $\begin{array}{l}\text { After } \\
\text { 2 days }\end{array}$ & $\begin{array}{l}\text { After } \\
\mathbf{6} \text { days }\end{array}$ & $\begin{array}{l}\text { After } \\
\mathbf{8} \text { days }\end{array}$ & $\begin{array}{l}\text { After } \\
\mathbf{1 0} \text { days }\end{array}$ & $\begin{array}{l}\text { After } \\
\mathbf{1 2} \text { days }\end{array}$ & $\begin{array}{l}\text { After } \\
\mathbf{1 8} \\
\text { days }\end{array}$ & Total \\
\hline Control & 0 & 2 & 3 & 4 & 5 & 0 & $14^{\mathrm{abc}}$ \\
\hline $\begin{array}{l}\text { Lavandula } \\
\text { coronopifola }\end{array}$ & 0 & 2 & 3 & 4 & 5 & 0 & $14^{\mathrm{abc}}$ \\
\hline $\begin{array}{l}\text { Ocimum } \\
\text { basilicum }\end{array}$ & 0 & 3 & 4 & 6 & 8 & 1 & $22^{\mathrm{c}}$ \\
\hline $\begin{array}{l}\text { Ocimum } \\
\text { filamentosum }\end{array}$ & 1 & 3 & 2 & 3 & 4 & 0 & $13^{\mathrm{abc}}$ \\
\hline $\begin{array}{l}\text { Orthosiphon } \\
\text { thymiflorus }\end{array}$ & 1 & 3 & 1 & 2 & 3 & 0 & $10^{\mathrm{ab}}$ \\
\hline $\begin{array}{l}\text { Otostegia } \\
\text { fruticosa }\end{array}$ & 1 & 2 & 3 & 4 & 5 & 0 & $15^{\mathrm{bc}}$ \\
\hline $\begin{array}{l}\text { Plectranthus } \\
\text { asirensis }\end{array}$ & 0 & 0 & 2 & 3 & 4 & 0 & $9^{\mathrm{a}}$ \\
\hline
\end{tabular}

of bees for new products present in feeds is almost the same that of pure sugar syrup regarding to the ingestion ability by bees.

The mean body weight of bees workers increased during the consumption of sugar syrup containing plant all tested plants extracts except for honey bee workers fed on diets containing Plectranthus asirensis extract that decrease the mean body weight although it is regarded as the highest plant extract consumed. So, we can say that Plectranthus asirensis extract may be considered as an inhibitor for bees' growth but Otostegia fruticosa extract may be considered as an inducer for bees' growth.

There is another strategy for bees' weight during the consumption of sugar syrup containing plant extract. The mean head weight of bees increased during the feeding except for Ocimum basilicum where the increment of weight became concentrated on body, not head. On the contrary, the effect of Plectranthus asirensis extract achieved a different strategy where the increment of weight became concentrated on head, not body. Otostegia fruticosa extract didn't follow either the two ways because it increased both head and body of bees as well.

According to bees' head diameter as a parameter for volume, Orthosiphon thymiflorus extract was the only extract that had both effects on weight and volume increment but Plectranthus asirensis was the only extract which suppressed weight and volume of bees.

The activity and development of the hypopharyngeal glands in bees are related to kind of ingested feed, the function performed in the nest and age. Under normal conditions, they start to function between the $3^{\text {rd }}$ and the $6^{\text {th }}$ days of a worker bee's life. They become fully developed in between the $6^{\text {th }}$ and the $14^{\text {th }}$ days and show the highest secreting activity (Krystyna, 2004).

Referred to the current study, the majority of studied plant extracts didn't influence greatly on the condition of pharyngeal glands in bees as for Lavandula coronopifola, Ocimum basilicum, and Orthosiphon thymiflorus but there was an obvious effect with increment in acini number and canal diameter for Ocimum filamentosum. Otostegia fruticosa extracts which had the highest promoted effect while Plectranthus asirensis extract 


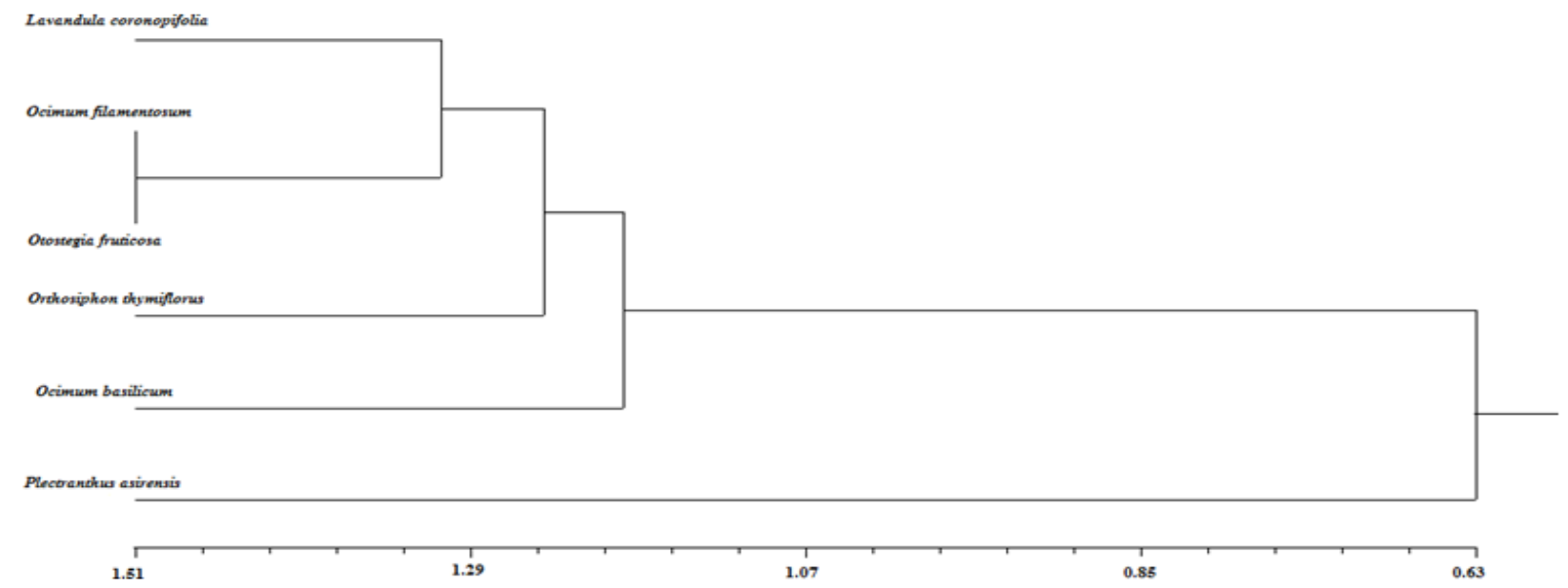

Figure 7: Phenogram for morphological traits of studied plant species with physiological conditions analysis on bees.

had the highest suppressed one on the condition of pharyngeal glands in bees.

According to larvae number, Ocimum basilicum and Otostegia fruticosa extract enhanced its number while Plectranthus asirensis extract had also the inhibited effect.

From the above studied, we can encourage Otostegia fruticosa extract as an enhanced additive for bees feeding during the growth and development while we can utilize Plectranthus asirensis extract as an inhibitor for growth any undesirable, injured or dangerous bees' nests.

Finally, we combined between morphological characters of studied members of Lamiaceae and all biological and histological conditions described before on bees. High similarity indices suggest that the species have a close genetic relationship between them (Sayed et al. 2009). Table 7 shows similarity indices between the six species where the high value indicated a close relationship between the two species and the low value indicated remote relationships between the two species. The highest similarity value $(0.75)$ was obtained between Ocimum basilicum and Ocimum filamentosum indicating that these two species were close to each other. On the other hand, the lowest similarity value (0.49) was recorded between Ocimum basilicum with Otostegia fruticosa and Plectranthus asirensis indicating that these were distantly related species.

The resulting phenogram (Figure 7) showed that the studied species have an average taxonomic distance of about (0.63). At this level, Plectranthus asirensis is separated from other species as a delimited group. The rest of the species are differentiated into two subgroups at about (1.18) level where Ocimum basilicum is split as a delimited subgroup. At (1.246) level the second group is differentiated into two clusters where Orthosiphon thymiflorus is delimited in one cluster. The second cluster included two sub-clusters; first one contained only one species; Lavandula coronopifola while the second contained two other species; Ocimum filamentosum and Otostegia fruticosa at (1.312) level.

\section{CONCLUSION}

1. Otostegia fruticosa has inducing substances which promote the physiological conditions of bees.
2. Plectranthus asirensis has inhibiting substances which suppress the physiological conditions of bees.

3. According to plant taxonomic trends, Plectranthus asirensis is separated from other members of the Lamiaceae family.

4. Ocimum basilicum and Ocimum filamentosum are close to each other while Otostegia fruticosa and Plectranthus asirensis are distantly related to each other.

\section{REFERENCES}

1. Lawrence, B. M. 1992. Chemical components of Labiate oils and their explotation. In-Advances in Labiate Science. Edn. Royal Botânic Gardens KEW. Whitstable., 399-436.

2. Ozkan, M. 2008. Glandular and eglandular hairs of Salvia recognita Fisch. \& Mey. (Lamiaceae) in Turkey. Bangladesh. J. Botany., 37: 93-95.

3. Licina, B.Z., Stefanovic, O. D., Vasic, S. M., Radojevic, I. D., Dekic, M. S., Comic, L. R. 2013. Biological activities of the extracts from wild growing Origanum vulgare L. Food. Control., 33:498-504.

4. Hellmich, R. L, Kulincevik, J. M., Rothenbuhler, R. C. 1985. Selection for high and low pollen-hoarding honeybees. J. Hered., 76:155-158.

5. Le Conte, Y., Mohammedi, A., Robinson, G. E. 2001. Primer effects of a brood pheromone on honeybee behavioural development. Proc. R. Soc. Lond. Biol. Sci., 268: 163-168.

6. Leoncini, I. 2002. Phe'romones et re' gulation sociale chez l'abeille, Apis mellifera L: Identification d'un inhibiteur $\mathrm{du}$ de'veloppement comportemental des ouvrie'res. PhD Dissertation., Institut National Agronomique ParisGrignon, Paris.

7. Leoncini, I., Le Conte, Y., Costagliola, G., Plettner, E., Toth, A. L., Wang, M., et al. 2004. Regulation of behavioral maturation by a primer pheromone produced by adult worker honey bees. Proc. Natl. Acad. Sci. USA., 101: 17559-17564.

8. Trhlin, M., Rajchard, J. 2011. Chemical communication in the honeybee (Apis mellifera L.): a review. Veterinarni. Medicina., 56: 2011: 265-273. 
9. Sultana, B., Anwar, F., Ashraf, M. 2009. Effect of extraction solvent/technique on the antioxidant activity of selected medicinal plant extracts. Molecules., 14: 2167-2180.

10. Rohlf, F. J. 1993. NTSYS-PC - Numerical Taxonomy and Multivariate Analysis. Appl. Biostat., New York, USA. 15

11. Richter, H. G., Dallwitz, M. J. 2000. Commercial timbers: descriptions, illustrations, identification, and information retrieval. English, French, German, and Spanish. Version.

12. El-Gazzar, A., Rabei, S. 2008. Taxonomic assessment of five numerical methods and its implications on the classification of Hyptis sl (Labiatae). Inter. J. Botany., 4: 85-92.

13. Gower, J.C. 1971. A general coefficient of similarity and some of its properties. Biometrics., 857-871.

14. Gower, J. C. 1982. Euclidean distance geometry. Math. Sci., 7: $1-14$
15. Sneath, P. H., Sokal, R. R. 1973. Numerical taxonomy. The principles and practice of numerical classification. San Francisco: Freeman., 213.

16. Nei, M. 1978. Estimation of average heterozygosity and genetic distance from a small number of individuals. Genetics., 89: 583-590.

17. Yao, Q., Yang, K., Pan, G., Romg, T. 2007. Genetic Diversity of Maize (Zea mays L.) Landraces from Southwest China Based on SSR Data. J. Genetic. Genome., 349: 851-860.

18. Krystyna, P. 2004. Effect of standardized plant herb extracts on general condition of the honeybee (Apis mellifera L.). Bull. Vet. Inst. Pulawy., 48: 415-419.

19. Sayed, M., Hasan, Z., M. Shafie, M., Shafie, B. 2009. Analysis of random amplified polymorphic DNA (RAPD) of Artemisia capillaries (Worm wood capillary) in east coast of Penisular Malaysia. J. World Appl. Sci., 6: 976-986. 